\title{
Optimization of Paclobutrazol Dose for Foliar and Drenching Applications under Water Deficit Stress in Chickpea (Cicer arietinum L.)
}

\author{
P. R. Soumya and Pramod Kumar*
}

Division of Plant Physiology, ICAR-Indian Agricultural research Institute, New Delhi (110 012), India

\section{Corresponding Author}

Pramod Kumar

e-mail: pramodk63@yahoo.com

\author{
Article History \\ Article ID: AR1734 \\ Received in $18^{\text {th }}$ November, 2016 \\ Received in revised form $19^{\text {th }}$ July, 2017 \\ Accepted in $3^{\text {rd }}$ August, 2017
}

\begin{abstract}
Chickpea (Cicer arietinum L.) is the fourth most important pulse crop rich in protein by virtue of $\mathrm{N}_{2}$ fixation. Water deficit is a major limitation in chickpea production. Paclobutrazol (PBZ), a potential triazole, has been reported to provide plant protection against abiotic stresses. Therefore, an experiment was conducted using kabuli chickpea variety Pusa 1108 (sensitive to water deficit) to identify its optimum dose for foliar and drenching application. Water deficit stress was imposed by withholding the water at vegetative stage. Just prior to water stress treatment, plants were treated exogenously with varying dose paclobutrazol for foliar $\left(0,30,60,90,120\right.$ and $\left.150 \mathrm{mg} \mathrm{l}^{\mathrm{I}^{-1}}\right)$ and drenching $(0$, $60,120,180,240$ and $300 \mathrm{mg} \mathrm{l}^{-1}$ ) applications. Maximum enhancement of relative water content (RWC), membrane stability index (MSI), photosynthetic rate $\left(\mathrm{P}_{N}\right)$, chlorophyll $\left(\mathrm{chl}_{\mathrm{a}}\right)$, chlorophyll $\mathrm{c}_{\mathrm{b}}\left(\mathrm{chl}_{\mathrm{b}}\right)$ and total chlorophyll during water deficit stress and after recovery were obtained with the foliar application of PBZ @ $60 \mathrm{mg} \mathrm{l}^{\mathrm{I}^{-1}}$ while for PBZ drenching @ $120 \mathrm{mg} \mathrm{l}^{-1}$. On an average, in general based on curve fitting of under taken physiological responses of chickpea to PBZ, optimum dose of PBZ foliar application was estimated 67.5 mg l$^{-1}$ while for PBZ drenching $127 \mathrm{mg} \mathrm{l}^{-1}$.
\end{abstract}

Keywords: Chickpea, optimum dose, paclobutrazol, photosynthesis, water deficit stress

\section{Introduction}

Chickpea is the most important crop representing about $27 \%$ of the land area under pulse, which contributes $33 \%$ of the total pulse production in india. In India, chickpea is grown over an area of $8.52 \mathrm{mha}$ with production of $8.83 \mathrm{mt}$ and average productivity of $1036 \mathrm{~kg} \mathrm{ha}^{-1}$ (Anonymous, 2014). Water deficit stress is one of the major abiotic stresses which adversely affect crop growth and yield. Water deficit affects many morphological features and physiological processes associated with plant growth and development in chickpea (Toker and Cagirgan, 1998). These changes include reduction of relative water content (RWC), diminished leaf water potential and turgor loss, closure of stomata and a decrease of cell enlargement and plant growth. Water deficit stress reduces plant growth by affecting photosynthesis, respiration, membrane stability index (MSI) and nutrient metabolism (Jaleel et al., 2007). Cell membrane stability has been used as a water deficit stress tolerance test (Agarie et al., 1995) and electrolyte leakage showed an increase with increasing water deficit (Gopi et aol., 2007). Water deficit stress also inhibits the photosynthesis of plants by affecting chlorophyll components and damaging the photosynthetic apparatus (Iturbe-Ormaetxe et al., 1998).
Since chickpea is traditionally cultivated in marginal and rainfed areas (Rao et al., 2002), therefore, drought is a major constraint in chickpea production that causes $40-50 \%$ reductions in yield globally (Ahmad et al., 2005).Therefore, an alternative approach that attracts more attention in this direction is the application of some external plant growth regulating molecules which can be used to achieve the stress tolerance in crops without compromising yield under water deficit stress. Paclobutrazol has innate ability to induce abiotic tolerance by increasing antioxidant enzymes and molecules in oxidative stressed plants. Paclobutrazol has been proved as an agent in stress amelioration in medicinal plants (Jaleel et al., 2007). PBZ has been used to provide plant protection against abiotic stresses viz chilling (Lin et al., 2006), water deficit stress (Zhu et al., 2004), flooding (Lin et al., 2006) and salinity (Kishor et al., 2009). Paclobutrazol was also reported to induce water deficit stress tolerance in ground nut (Sankar et al., 2007). Though chickpea is grown in rainfed areas despite that to date, not a single report is available on the PBZ induced water stress tolerance in chickpea. Therefore, a preliminary study was carried out with an objective to identify PBZ optimum dose for foliar and drenching application in chickpea.

\section{Materials and Methods}




\subsection{Plant material and growth conditions}

Present study was carried out in pot culture inside the net house of Division of Plant Physiology, IARI, New Delhi-110012 (latitude of $28^{\circ} \mathrm{N}$ and longitude of $77^{\circ} \mathrm{E}$, and about 250 $\mathrm{m}$ (Above mean sea level) to identify optimum dose of paclobutrazol for foliar and drenching applications. Seed of Kabuli chickpea variety Pusa 1108 was obtained from Division of Genetics, Indian Agricultural Research Institute, New Delhi. Sowing was done in 12 inch diameter earthen pots filled with clay loam soil and farmyard manure in 4:1 ratio during winter season inside net house of Division of Plant Physiology, IARI, and New Delhi. All recommended agronomic practices were followed to raise the healthy crop plants. Recommended basal dose of fertilizers in the form of urea, SSP and MOP were applied to raise the healthy crop.

\subsection{Experimental details and sample collection}

A pot experiment was conducted in complete randomized design using with three replications. Water stress was imposed at vegetative stage in chickpea variety by restricting water supply until the appearance of severe symptoms of wilting. Before imposition of water stress plants were treated exogenously with varying dose paclobutrazol (Sigma-Aldrich) for foliar $\left(0,30,60,90,120\right.$ and $\left.150 \mathrm{mg} \mathrm{l}^{-1}\right)$ and drenching (0, $60,120,180,240$ and $300 \mathrm{mg} \mathrm{l}^{-1}$ ) applications. Volume of PBZ

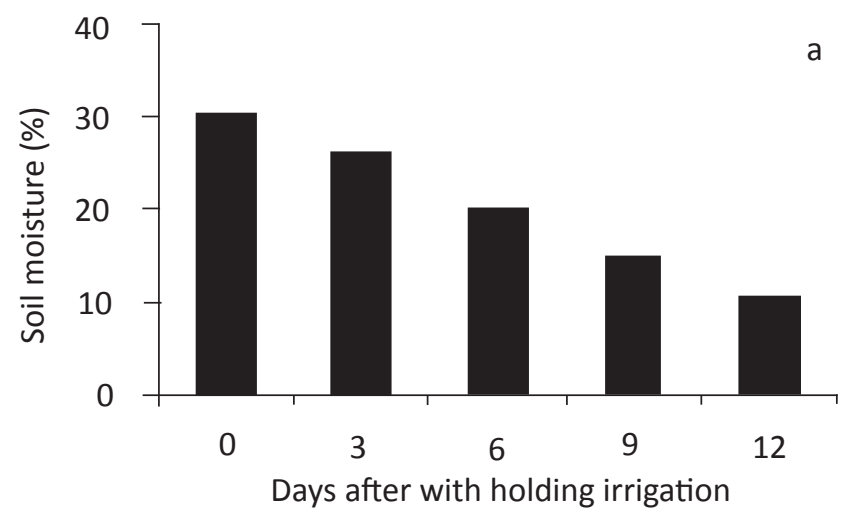

solutions prepared with varying doses was kept 50 and 100 $\mathrm{ml} \mathrm{pot}{ }^{-1}$ for foliar and drenching applications respectively. Plant samples were taken on $12^{\text {th }}$ days after withholding water during imposed water deficit stress. After sampling, water deficit stress was terminated and further sampling was done during recovery period i.e. on $6^{\text {th }}$ day after water stress termination. Observations were recorded on photosynthetic pigments, photosynthesis, MSI, RWC. Based on the physiological response data of both foliar and drenching applications optimum dose were identified by curve fitting.

\subsection{Soil moisture content}

Soil moisture content was estimated periodically during imposed water stress treatment at vegetative stage by gravimetric method. Soil sample was taken from pot at 10 $\mathrm{cm}$ depth using auger. For each sample $100 \mathrm{~g}$ fresh weight of soil was recorded using a weighing balance. Then the sample was kept in the oven at $105^{\circ} \mathrm{C}$, and dried till constant weight was achieved. The soil moisture content was calculated by the following formula (Faulkner et al., 1989) and expressed in percentage (\%). Fully saturated soil at $100 \%$ capacity (FC) had $30 \%$ moisture. By using this relation of field capacity with soil moisture FC (\%) was estimated at different water deficit stressed period (Figure 1).

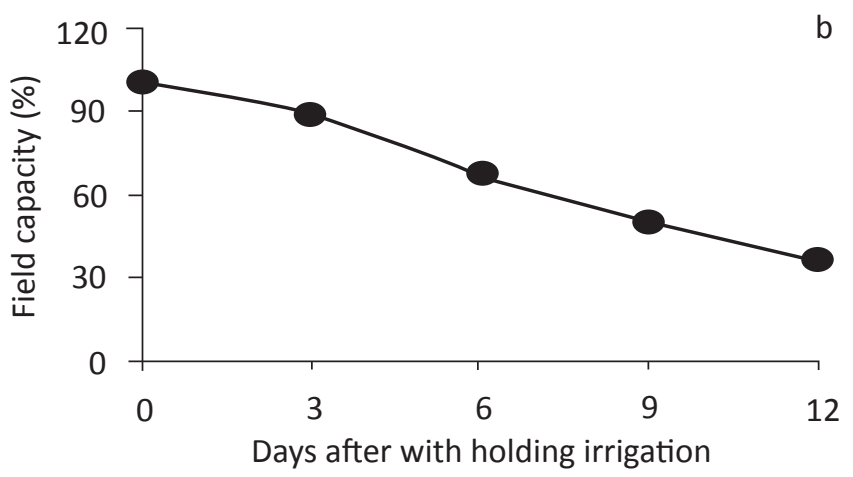

Figure 1: Soil moisture content (a) and field capacity (b) recorded during the course of imposed water deficit stresscondition

\subsection{Relative water content}

Leaf relative water content (RWC) was estimated by recording the turgid weight of $1 \mathrm{~g}$ fresh leaf samples by keeping in water for $4 \mathrm{~h}$, followed by drying in hot air oven at $70{ }^{\circ} \mathrm{C}$ till constant weight was achieved (Weatherley, 1950).

$$
\text { RWC }=[(\text { Fresh wt.-Dry wt. }) /(\text { Turgid wt.-Dry wt. })] \times 100
$$

\subsection{Membrane stability index}

Membrane stability index (MSI) was estimated according to the method described by Premachandra et al. (1990). For estimation of membrane stability index 100 mg leaf material, in two sets, was taken in test tubes containing $10 \mathrm{ml}$ of double distilled water. One set was heated at $40{ }^{\circ} \mathrm{C}$ for $30 \mathrm{~min}$ in a water bath, and the electrical conductivity of the solution was recorded on a conductivity bridge $\left(C_{1}\right)$. Second set was boiled at $100{ }^{\circ} \mathrm{C}$ in a boiling water bath for $10 \mathrm{~min}$, and its conductivity was measured on a conductivity bridge $\left(C_{2}\right)$. Membrane stability index (MSI) was calculated as:

$\mathrm{MSI}=\left[1-\left(\mathrm{C}_{1} / \mathrm{C}_{2}\right)\right] \times 100$

\subsection{Photosynthetic rate}

Rate of photosynthesis was measured using portable Infrared Gas Analyzer (IRGA), model LI-6400XT Model (Li-COR Ltd., Lincoln, Nebraska, USA). Data on rate of photosynthesis ( $\mu \mathrm{mol} \mathrm{CO}_{2} \mathrm{~m}^{-2} \mathrm{~s}^{-1}$ ) were recorded on clear sunny day between 10 to 11.30 am by providing artificial light source of intensity $1200 \mu \mathrm{mol} \mathrm{m} \mathrm{m}^{-2} \mathrm{~s}^{-1}$ during water deficit stress and after water deficit stress termination (during recovery). Fourth fully expanded leaf from top was used for the measurement of photosynthesis using fixed exposed area of leaf. 


\subsection{Chlorophyll content}

Chlorophylls content were estimated as per the method described by Hiscox and Israelstam (1979). The procedure for estimation of chlorophyll content in plants is based on the absorption of light by chlorophyll extracts prepared by incubating the leaf tissues in dimethyl sulfoxide (DMSO). DMSO renders plasmalemma permeable thereby, causing the leaching of the pigments. Fifty mg fresh leaf samples were added to the test tubes containing $10 \mathrm{ml}$ DMSO. Tubes were kept in dark for $4 \mathrm{~h}$ at $65^{\circ} \mathrm{C}$. Then the samples were taken out cooled at room temperature and the absorbance was recorded at 663 and $645 \mathrm{~nm}$ using DMSO as blank and was expressed as $\mathrm{mg} \mathrm{g}^{-1} \mathrm{dry}$ wt. The absorbance of the known volume of solution containing known quantity of leaf tissue at two respective wavelengths (663 and 645) was determined for chlorophylls content. Chlorophyll a, chlorophyll b and total chlorophyll content were estimated using the formula given by Arnon (1949).

$$
\begin{aligned}
& \text { Chlorophyll 'a' }=\left(12.7 \times \mathrm{A}_{663}-2.69 \times \mathrm{A}_{645}\right) \times \mathrm{V} / \mathrm{W} \times 1000 \\
& \text { Chlorophyll ' } \mathrm{b} \text { ' }=\left(22.9 \times \mathrm{A}_{645}-4.68 \times \mathrm{A}_{663}\right) \times \mathrm{V} / \mathrm{W} \times 1000 \\
& \text { Total chlorophyll }=\left(20.2 \times \mathrm{A}_{645}+8.02 \times \mathrm{A}_{663}\right) \times \mathrm{V} / \mathrm{W} \times 1000
\end{aligned}
$$

Where,

$$
A_{663}=\text { Absorbance values at } 663 \mathrm{~nm}
$$

$A_{645}=A$ bsorbance values at $645 \mathrm{~nm}$

$W=$ Weight of the sample in $g$

$\mathrm{V}=$ Volume of the solvent used $(\mathrm{ml})$

\section{Results and Discussion}

For the identification of optimum dose of PBZ for foliar application varying doses of PBZ $(0,30,60,90,120$ and $150 \mathrm{mg} \mathrm{l}^{-1}$ ) were applied on plants at vegetative stage. All physiological parameters (RWC, MSI, photosynthetic rate and photosynthetic pigments) were increased with increasing PBZ dose upto $60 \mathrm{mg} \mathrm{l}^{-1}$ and decreased thereafter at its higher doses during imposed water deficit and after water stress termination (during recovery) in both the varieties. Based on curve fitting, optimum response of chickpea in term of leaf RWC was obtained at PBZ dose of $72 \mathrm{mg} \mathrm{l}^{-1}$ under water deficit stress as well as during recovery (Table 1 and Figure 2a). Similarly based on MSI values, optimum PBZ dose for foliar application was estimated $60 \mathrm{mg} \mathrm{l}^{-1}$ under water deficit (Figure 2c). While after water deficit stress termination during recovery optimum PBZ foliar dose was $90 \mathrm{mg} \mathrm{l}^{-1}$ (Figure 2c). Based on $P_{N}$ values optimum PBZ foliar dose was found $90 \mathrm{mg}$ $\mathrm{I}^{-1}$ under water deficit, while during recovery plants had 60 $\mathrm{mg} \mathrm{l}^{-1}$ PBZ optimum dose (Figure 2e). Similarly, based on leaf chla and chlb contents values optimum PBZ foliar application dose was estimated $60 \mathrm{mg} \mathrm{l}^{-1}$ both under water deficit as well as during recovery (Figure $3 a$ and Figure $3 \mathrm{c}$ ). However, total chlorophyll contents indicated $66 \mathrm{mg} \mathrm{l}^{-1} \mathrm{PBZ}$ optimum dose for foliar application under water deficit and $60 \mathrm{mg} \mathrm{l}^{-1}$ during recovery (Figure 3e). On an average, in general based on curve fitting of under taken physiological responses of chickpea to PBZ, optimum dose of PBZ foliar application was estimated $67.5 \mathrm{mg} \mathrm{l}^{-1}$ (Table 1 ).

Further, for optimizing PBZ dose for drenching, varying dose of PBZ (0,60,120,180, 240 and $\left.300 \mathrm{mg} \mathrm{l}^{-1}\right)$ were used for drenching before imposing water deficit stress. PBZ drenching treatments also increased RWC, MSI, $\mathrm{P}_{\mathrm{N}^{\prime}} \mathrm{chl}_{\mathrm{a}^{\prime}}, \mathrm{chl}_{\mathrm{b}}$ and total chlorophyll with increasing dose of PBZ up to $120 \mathrm{mg} \mathrm{l}^{-1}$ and decreased at its higher dose during imposed water deficit and recovery in chickpea. Based on curve fitting using leaf RWC values optimum PBZ dose for drenching was estimated 132 $\mathrm{mg} \mathrm{l}^{-1}$ under water deficit and $120 \mathrm{mg} \mathrm{l}^{-1}$ during recovery (Fig. $2 \mathrm{~b})$. Similarly, based on curve fitting $\mathrm{MSI}, \mathrm{P}_{\mathrm{N}^{\prime}}$ chl $\mathrm{b}_{\mathrm{b}}$ and total chlorophyll values also indicated $120 \mathrm{mg} \mathrm{l}^{l^{-1}} \mathrm{PBZ}$ optimum dose for drenching application under water deficit as well as during recovery (Figure 2 ( $d$ and f); Figure 3 ( $d$ and f). However, chl content indicated higher optimum PBZ dose for drenching i.e. $132 \mathrm{mg} \mathrm{l}^{-1}$ under water deficit stress and $180 \mathrm{mg} \mathrm{l}^{-1}$ during recovery after water deficit stress termination (Figure $3 b$ ). On an average, based on curve fitting using physiological responses values of chickpea to PBZ, optimum dose of PBZ drenching application was estimated $127 \mathrm{mg} \mathrm{l}^{-1}$ (Table 1).

Based on recorded RWC values with varying PBZ doses, estimated optimum PBZ dose for foliar and drenching applications under water deficit stress condition were 72 $\mathrm{mg} \mathrm{l}^{-1}, 132 \mathrm{mg} \mathrm{l}^{-1}$ similarly, after water deficit termination during recovery PBZ optimum doses were $72 \mathrm{mg} \mathrm{l}^{-1}, 120 \mathrm{mg}$ $\mathrm{I}^{-1}$ for foliar and drenching application respectively. RWC was decreased under water deficit condition while PBZ applications improved leaf RWC in chickpea variety. Reduction in RWC of leaves was observed in plants exposed to water deficit conditions. There are reports that PBZ treated plants of Curcuma alismatifolia Gagnep (Jungklang and Saengnil, 2012) and cucumber seedling (Baninasab and and Ghobadi, 2011) had higher value of RWC. Paclobutrazol has been reported to enhance water retention and thus increased survival in wheat (Aly and Lathif, 2011) and barley (Rady and Gaballah, 2012) by accelerating stomatal response and reducing transpiration rate under water deficit condition.

Similarly, based on MSI values estimated optimum PBZ dose for foliar and drenching applications under water deficit stress condition were $60 \mathrm{mg} \mathrm{l}^{-1}$ and $120 \mathrm{mg} \mathrm{l}^{-1}$ respectively while during recovery optimum PBZ doses for foliar and drenching applications were calculated $90 \mathrm{mg} \mathrm{l}^{-1}, 120 \mathrm{mg} \mathrm{l}^{-1}$. MSI was reduced under water deficit. The inhibition of electrolyte leakage indicates ability of PBZ in maintaining the membrane integrity (Fletcher et al., 2000) of plants. PBZ altered the sterol biosynthesis and changed the composition of sterol in the plasma membrane (Burden et al., 1987). In addition, upregulation of stress protective biomolecules in PBZ treated plants enhances the capacity to limit the damage caused by species of reactive oxygen (Fletcher and Hofstra, 1990). PBZ has been reported to reduce electrolyte leakage in wheat 
Table1: Optimization of PBZ dose for foliar and drenching application under water deficit condition and after water deficit stress termination during recovery

\begin{tabular}{|c|c|c|c|c|c|c|c|}
\hline \multirow{2}{*}{$\begin{array}{l}\text { Sl. } \\
\text { NI. }\end{array}$} & \multirow{2}{*}{$\begin{array}{l}\text { Parameters } \\
\text { used for op- } \\
\text { timizing PBZ } \\
\text { dose }\end{array}$} & \multicolumn{3}{|c|}{ Under water deficit stress } & \multicolumn{3}{|c|}{ After water deficit stress termination (during recovery) } \\
\hline & & Regression equation & $\mathrm{R}^{2}$ & $\begin{array}{l}\text { Estimated } \\
\text { optimum } \\
\text { dose }\left(\mathrm{mg} \mathrm{l}^{-1}\right)\end{array}$ & Regression equation & $\mathrm{R}^{2}$ & $\begin{array}{l}\text { Estimated } \\
\text { optimum } \\
\text { dose }\left(\mathrm{mg} \mathrm{l}^{-1}\right)\end{array}$ \\
\hline
\end{tabular}

\begin{tabular}{|c|c|c|c|c|c|c|c|}
\hline \multirow[b]{2}{*}{1.} & \multicolumn{7}{|c|}{ Foliar Application } \\
\hline & RWC & $\begin{array}{l}y=-0.001 x^{2}+ \\
0.177 x+51.37\end{array}$ & 0.850 & 72 & $y=-0.000 x^{2}+0.073 x+81.17$ & 0.922 & 72 \\
\hline 2. & MSI & $\begin{aligned} y=- & -0.000 x^{2}+0.042 x \\
& +72.56\end{aligned}$ & 0.790 & 60 & $y=-0.000 x^{2}+0.106 x+65.24$ & 0.844 & 90 \\
\hline 3. & $P_{N}$ & $\begin{array}{l}y=-0.000 x^{2}+0.132 x+ \\
9.334\end{array}$ & 0.920 & 90 & $y=-0.000 x^{2}+0.059 x+14.84$ & 0.823 & 60 \\
\hline 4. & $\mathrm{Chl}_{\mathrm{a}}$ & $\begin{array}{c}y=-5 E- \\
05 x^{2}+0.005 x+0.946\end{array}$ & 0.718 & 60 & $y=-8 E-05 x^{2}+0.010 x+1.796$ & 0.837 & 60 \\
\hline 5. & $\mathrm{Chl}_{\mathrm{b}}$ & $\begin{array}{c}y=-1 E- \\
05 x^{2}+0.001 x+0.252\end{array}$ & 0.959 & 60 & $y=-1 E-05 x^{2}+0.001 x+0.202$ & 0.943 & 60 \\
\hline 6. & Total Chl & $\begin{array}{c}y=-5 E- \\
05 x^{2}+0.005 x+0.946\end{array}$ & 0.718 & 66 & $y=-5 E-05 x^{2}+0.006 x+2.155$ & 0.833 & 60 \\
\hline & Mean & & & 68 & Mean & & 67 \\
\hline \multicolumn{7}{|c|}{$\begin{array}{l}\text { Grand mean }=(\text { Mean under water deficit stress+mean after water deficit stress termination }) / 2= \\
\text { Drenching application }\end{array}$} & 67.5 \\
\hline 1. & RWC & $\begin{array}{l}y=-0.000 x^{2}+0.168 x+ \\
48.72\end{array}$ & 0.795 & 132 & $y=-0.000 x^{2}+0.079 x+77.13$ & 0.846 & 120 \\
\hline 2. & MSI & $\begin{array}{l}y=-0.000 x^{2}+0.045 x+ \\
68.34\end{array}$ & 0.715 & 120 & $y=-0.000 x^{2}+0.038 x+68.93$ & 0.767 & 120 \\
\hline 3. & $P_{N}$ & $\begin{aligned} y=-0.000 x^{2}+0.070 x \\
+11.5\end{aligned}$ & 0.745 & 120 & $y=-0.000 x^{2}+0.131 x+12.47$ & 0.813 & 120 \\
\hline 4. & $\mathrm{Chl}_{\mathrm{a}}$ & $\begin{array}{l}y=-2 E-05 x^{2}+0.005 x+ \\
1.073\end{array}$ & 0.701 & 132 & $y=-1 E-05 x^{2}+0.004 x+1.294$ & 0.775 & 180 \\
\hline 5. & $\mathrm{Chl}_{\mathrm{b}}$ & $\begin{array}{l}y=-1 E-05 x^{2}+0.003 x+ \\
\quad 0.372\end{array}$ & 0.970 & 120 & $y=-3 E-06 x^{2}+0.000 x+0.199$ & 0.928 & 120 \\
\hline 6. & Total Chl & $\begin{array}{c}y=-3 E-05 x^{2}+0.008 x+ \\
1.486\end{array}$ & 0.976 & 120 & $y=-2 E-05 x^{2}+0.005 x+1.474$ & 0.609 & 120 \\
\hline & Mean & & & 124 & Mean & & 130 \\
\hline \multicolumn{7}{|c|}{ Grand mean $=($ Mean under water deficit stress + Mean after water deficit stress termination $) / 2=$} & 127 \\
\hline
\end{tabular}

(Aly and Latif, 2011) and horse chestnut (Percival and Noviss, 2008) during water deficit stress.

Based on $\mathrm{P}_{N^{\prime}}$ chickpea plants performed better under optimum PBZ doses for foliar and drenching application during water deficit stress condition were $90 \mathrm{mg} \mathrm{l}^{-1}, 120 \mathrm{mg} \mathrm{l}^{-1}$ and after water deficit termination, showed response to optimum doses of $60 \mathrm{mg} \mathrm{l}^{-1}, 120 \mathrm{mg} \mathrm{l}^{-1}$ for foliar and drenching applications respectively. PBZ enhanced the $P_{N}$ in chickpea plants. Paclobutrazol has also been reported to enhance net photosynthesis rate in triticale (Berova and Zlatev, 2003), Setaria italica (Bisht et al., 2007) and horse chestnut
(Percival and Noviss, 2008). The higher chlorophyll content in the leaves, leading to higher photosynthesis in the triazole treated plants (Feng et al., 2003). On the other hands, PBZ also increased activity of RUBP-carboxylase and thus rate of photosynthesis in peanut (Yan and Pan, 1992). Further, Paclobutrazol was reported to significantly enhance zeatin and zeatin riboside (Zhu et al., 2004) and cytokinins protect photosynthetic machinery.

Estimated PBZ optimum doses based on $\mathrm{chl}_{\mathrm{a}^{\prime}} \mathrm{chl}_{\mathrm{b}^{\prime}}$ and total chlorophylls values for foliar were $60 \mathrm{mg} \mathrm{l}^{-1}, 60 \mathrm{mg} \mathrm{l}^{-1}$ and $66 \mathrm{mg}$ $1^{-1}$ respectively during water deficit stress. Similarly, estimated 
Foliar application
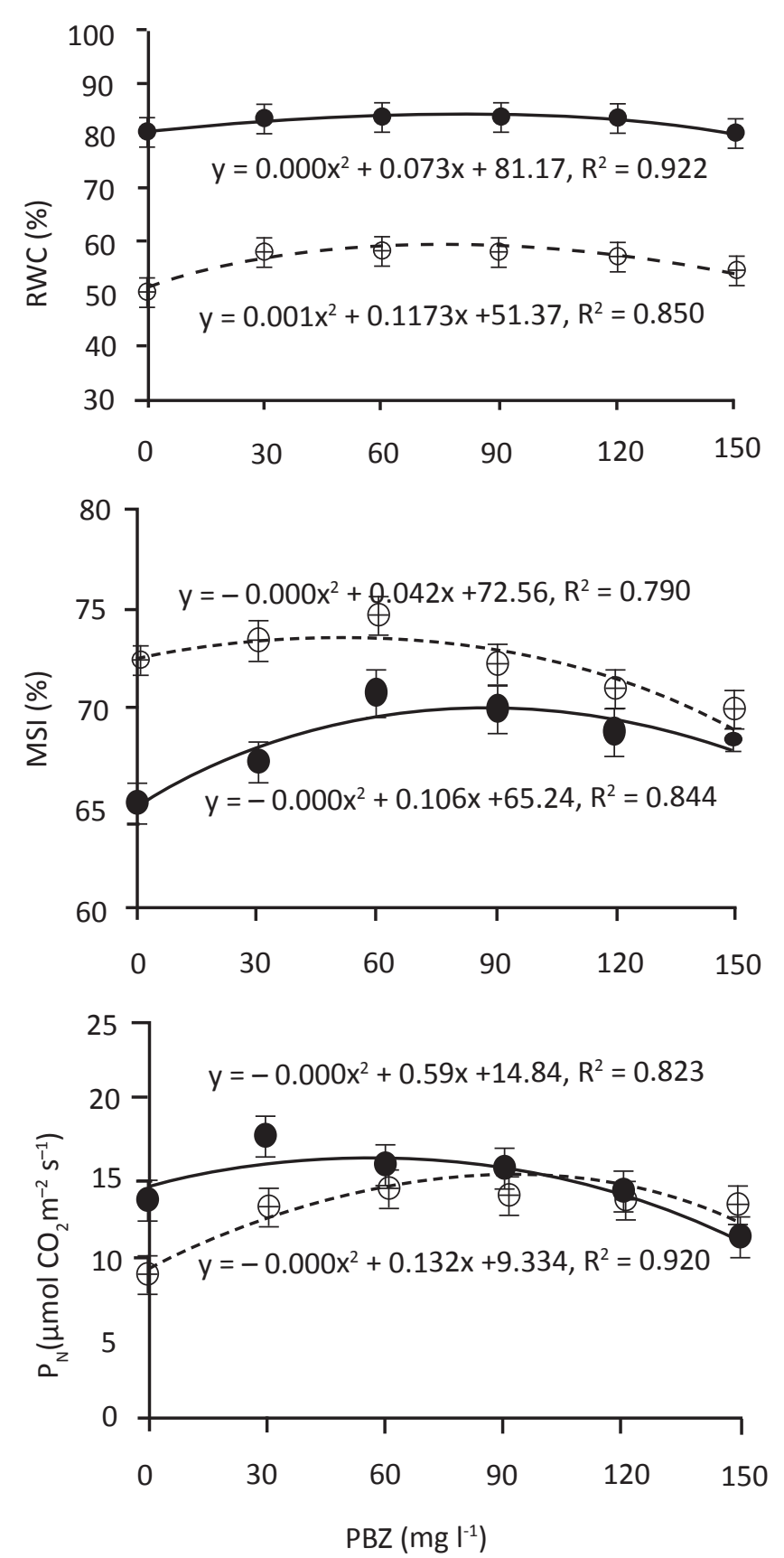

Drenching application
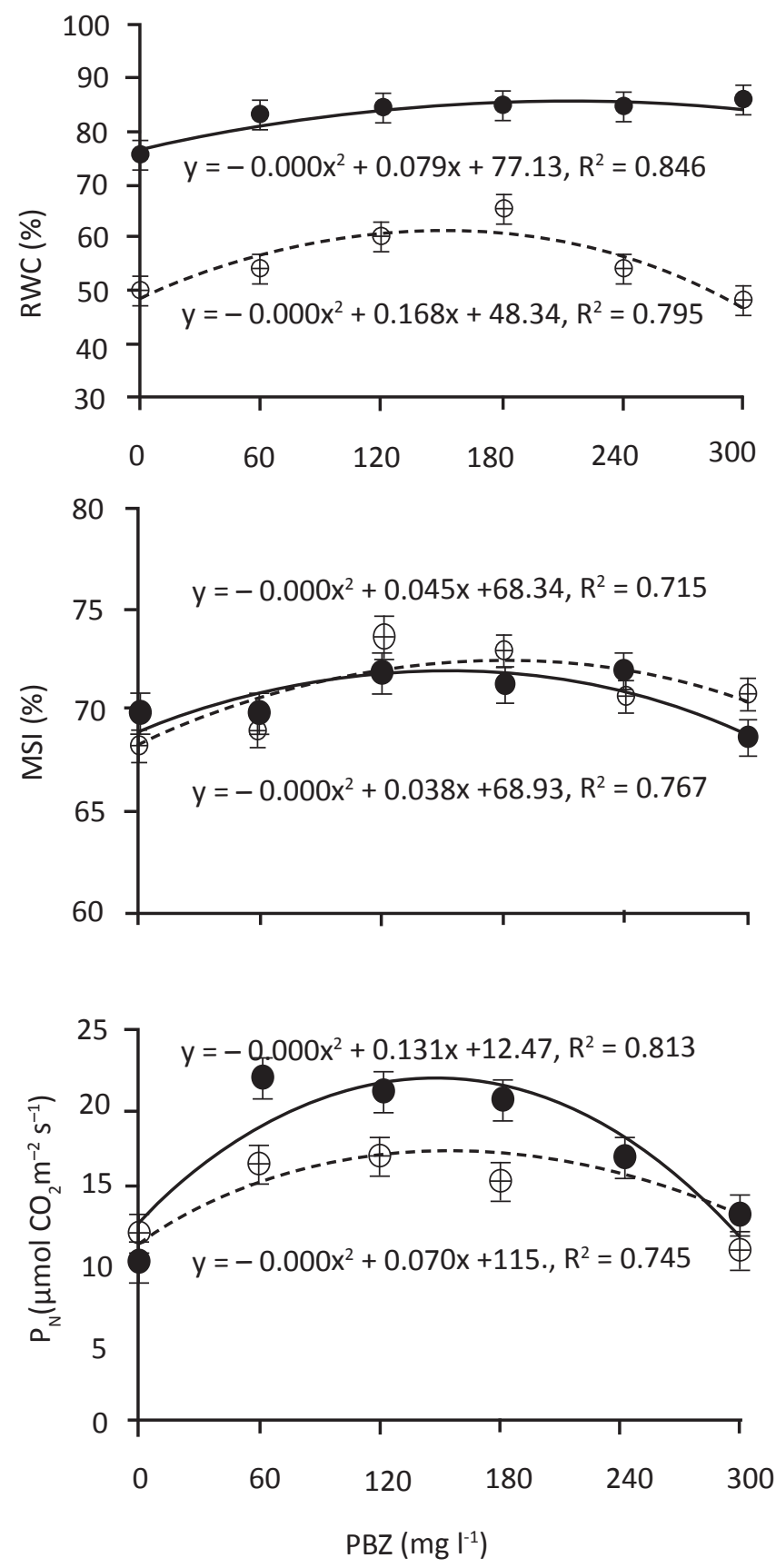

Figure 2: Relative water content, membrane stability index and photosynthesis rate response of chickpea plants to foliar and drenching application of PBZ under water deficit stress (•®) ) and during recovery (م) ) .

(a) RWC response to PBZ foliar application under water deficit stress and during recovery, b) RWC response to PBZ drenching application under water deficit stress and during recovery, c) MSI response to PBZ foliar application under water deficit stress and during recovery, d) MSI response to PBZ drenching application under water deficit stress and during recovery, e) $P N$ response to $P B Z$ foliar application under water deficit stress and during recovery $f$ ) $P_{N}$ response to PBZ drenching application under water deficit stress and during recovery).

PBZ optimum dose based on $\mathrm{Chl}_{\mathrm{a}^{\prime}} \mathrm{Chl}_{\mathrm{b}^{\prime}}$ and total chlorophylls values for drenching application during water deficit stress condition were $132 \mathrm{mg} \mathrm{l}^{-1}, 120 \mathrm{mg} \mathrm{l}^{-1}, 120 \mathrm{mg} \mathrm{l}^{-1}$ respectively. During recovery also calculated optimum dose based on $\mathrm{chl}_{\mathrm{a}^{\prime}}$ chlorophylls values (chl and total chlorophylls) for foliar were $60 \mathrm{mg} \mathrm{l}^{-1}$. Similarly, PBZ optimum dose based on $\mathrm{chl}_{\mathrm{a}} \mathrm{chl}_{b}$ and total chlorophylls values for drenching application were 180 $\mathrm{mg} \mathrm{l}^{-1}, 120 \mathrm{mg} \mathrm{l}^{-1}$ and $120 \mathrm{mg} \mathrm{l}^{-1}$ respectively. PBZ applications 
Foliar application
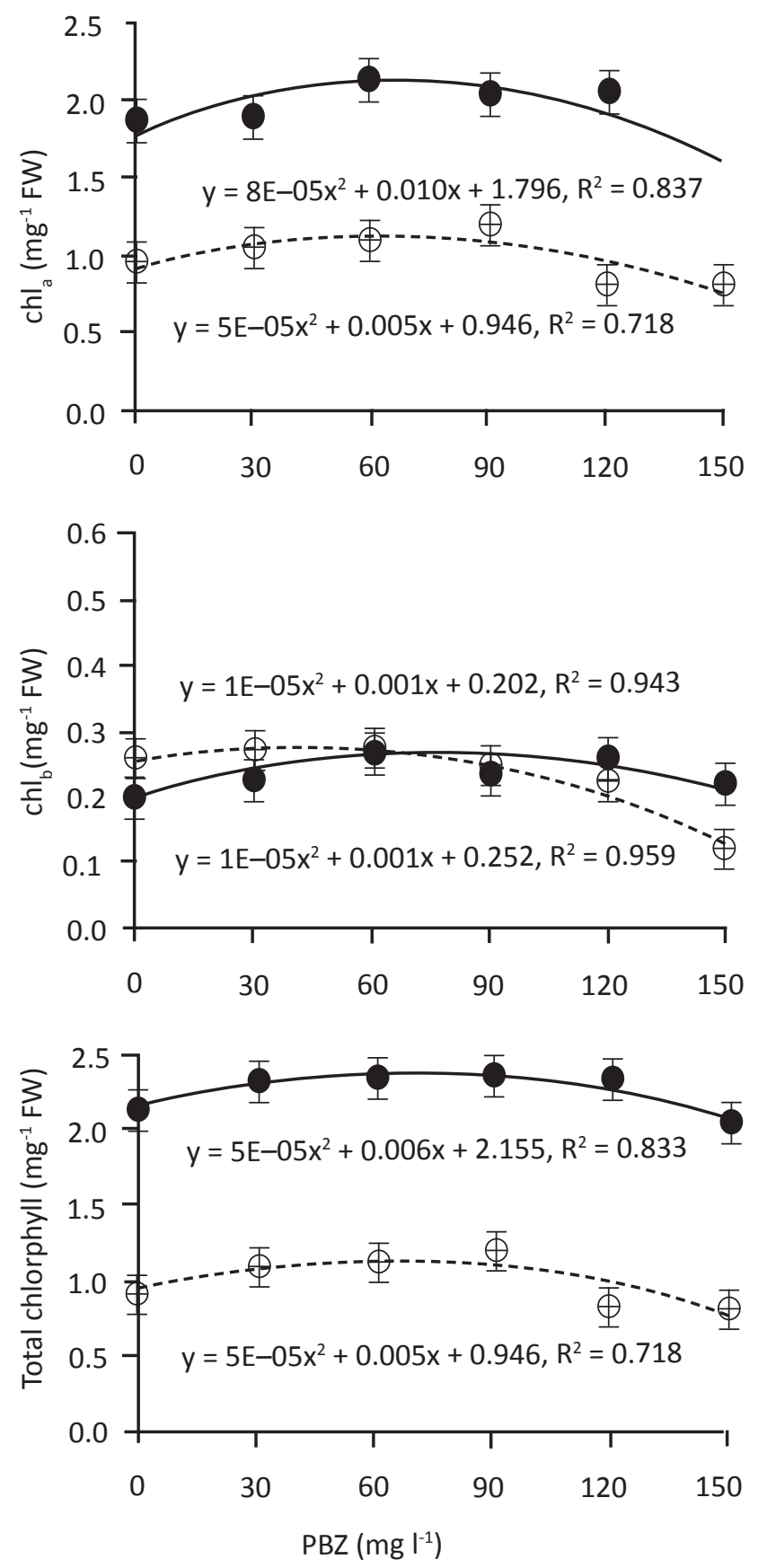

Drenching application
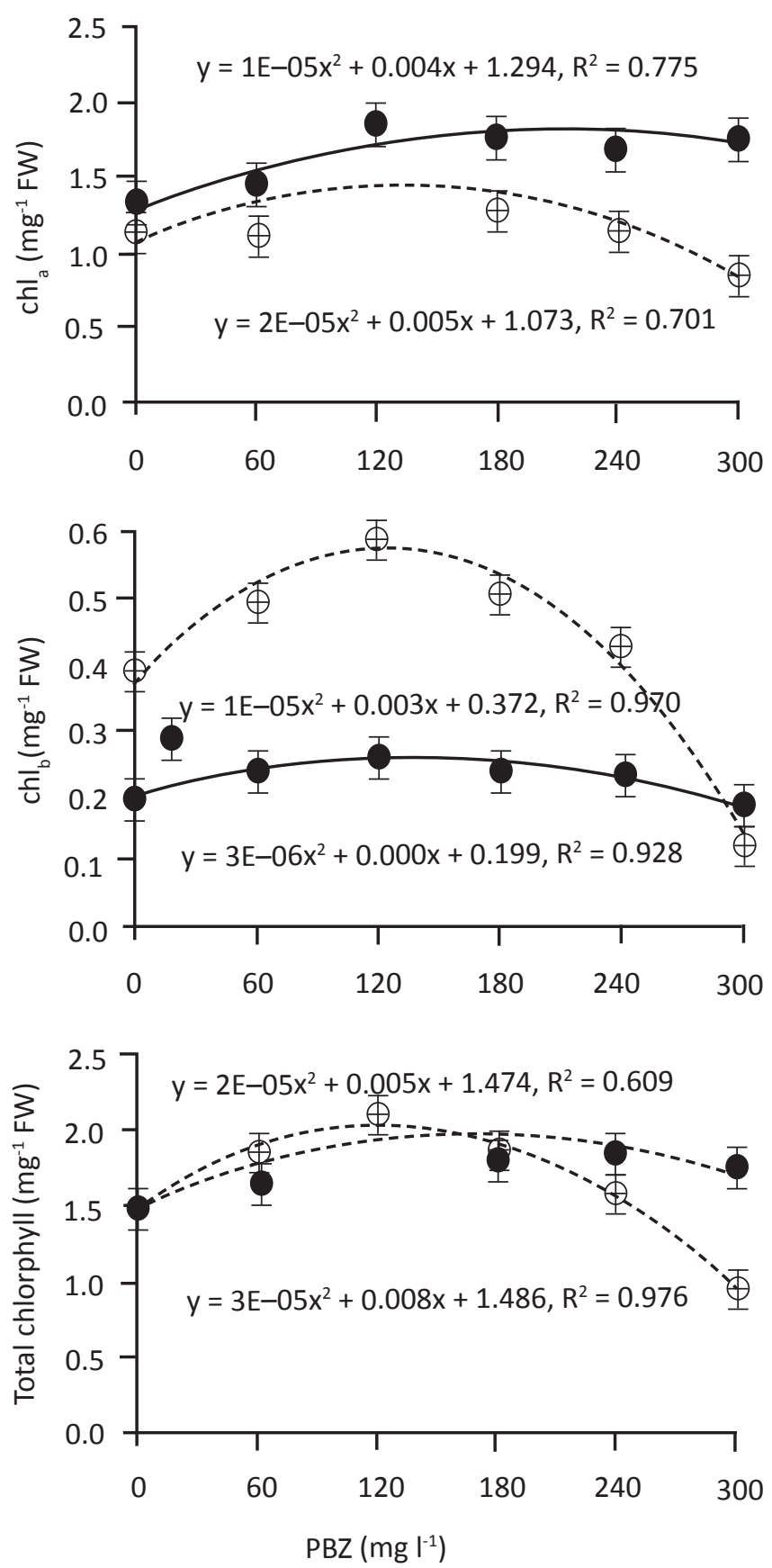

Figure 3: Chlorophyll a ( $\left.\mathrm{chl}_{\mathrm{a}}\right)$, chlorophyll b $\left(\mathrm{chl}_{\mathrm{b}}\right)$ and total chlorophyll response of chickpea plants to foliar and drenching application of PBZ under water deficit stress and during recovery. (a) chl response to PBZ foliar application under water deficit stress and during recovery, (b) chl response to PBZ drenching application under water deficit stress and during recovery, (c) $\mathrm{chl}_{\mathrm{b}}$ response to PBZ foliar application under water deficit stress and during recovery, (d) chl response of chickpea plants to PBZ drenching application under water deficit stress and during recovery, (e) Total chlorophyll response to PBZ foliar application under water deficit stress and during recovery $(\mathrm{f})$ Total chlorophyll response to PBZ drenching application under water deficit stress and during recovery).

improved or maintained higher level of photosynthetic pigments under water stressed condition in chickpea variety by increasing level of cytokinins and antioxidant activity.
PBZ application has been reported to increase level of pigments in cucumber (Baninasab and Ghobadi, 2011) and wheat (Nouriyani et al., 2012). The decrease in chlorophyll 
under water deficit stress is mainly the result of damage to chloroplasts caused by active oxygen species (Smirnoff, 1995). A reduction in photosynthetic pigments content was reported in water stressed cotton (Massacci et al., 2008), horse chestnut and Catharanthus roseus (Jaleel et al., 2007). PBZ is known to block the production of gibberellins, resulting in utilization of intermediates of gibberellin synthesis to facilitate increased phytyl production (Chaney, 2003) which should have resulted in higher level of chlorophylls and dark green leaf colour as was observed during the present study.

In general, RWC, MSI, photosynthesis rate, $\mathrm{chl}_{\mathrm{a}^{\prime}} \mathrm{chl}_{\mathrm{b}^{\prime}}$ and total chlorophylls increased with increasing dose of PBZ used for foliar and drenching applications during water deficit stress condition as well as after water deficit termination during recovery. On an average, in general based on curve fitting of RWC, MSI, photosynthetic rate, $\mathrm{chl}_{\mathrm{a}}, \mathrm{chl}_{b}$ and total chlorophyll responses of chickpea to PBZ, optimum dose of PBZ during water deficit stress and after water deficit stress termination (during recovery), were estimated $67.5 \mathrm{mg} \mathrm{l}^{-1}$ and $127 \mathrm{mg} \mathrm{l}^{-1}$ for foliar and drenching applications respectively.

Maximum enhancement of RWC, MSI, $\mathrm{P}_{\mathrm{N}^{\prime}} \mathrm{Chl}_{\mathrm{a}^{\prime}} \mathrm{Chl}_{\mathrm{b}}$ and total chl during water deficit stress and after recovery were obtained with the foliar application of PBZ @ $60 \mathrm{mg} \mathrm{l}^{-1}$ while for PBZ drenching @ $120 \mathrm{mg} \mathrm{l}^{-1}$ However at higher doses there was either stagnation or reduction in the values of aforementioned parameters probably due to the meatabolic imbalances by vigorously altering the level of endogenous hormones at higher dose of PBZ. Similarly, higher dose of PBZ has also been reported inhibitory in tomato (Rahman et al., 1989).

\section{Conclusion}

Maximum enhancement of RWC, MSI, photosynthetic rate, chla, chlb and total chlorophyll were recorded with the foliar application of PBZ @ $60 \mathrm{mg} \mathrm{l}^{-1}$ and for PBZ drenching @ $120 \mathrm{mg} \mathrm{l}^{-1}$. On an average, based on curve fitting of physiological responses, optimum dose of PBZ foliar application was estimated $67.5 \mathrm{mg} \mathrm{l}^{-1}$ while for PBZ drenching $127 \mathrm{mg} \mathrm{l}^{l^{-1}}$. Physiological performances were improved with the applications of PBZ. PBZ treated plants showed higher level of RWC by altering stomatal response. Further, PBZ treatments increased chlorophylls content by inducing alteration in hormonal biosynthesis pathways; thus enhanced the rate of photosynthesis.

\section{Acknowledgement}

Authors duly acknowledge to IARI Authorities for providing facilities during the course of investigation and IARI Scholarship to first author, Ms. Soumya, P.R., is gratefully acknowledged.

\section{References}

Agarie, S., Hanaoka, N., Kubota, F., Agata, W., Kaufman, P.B., 1995. Measurement of cell membrane stability evaluated by electrolyte leakage as a drought and heat tolerance test in rice (Oryza sativa L.). Journal of the Faculty of Agriculture, Kyushu University 40, 233-240.

Ahmad, F., Gaur, P., Croser, J., 2005. Chickpea (Cicer arietinum L.): Genetic resources, chromosome engineering and crop improvement. In: Singh, R., Jauhar, P. (Eds.), Grain Legumes Vol.1, CRC Press, USA, 185-214.

Aly, A., Latif, H., 2011. Differential effects of paclobutrazol on water stress alleviation through electrolyte leakage, phytohormones, reduced glutathione and lipid peroxidation in some wheat genotypes (Triticum aestivum L.) grown in vitro. Romanian Biotechnology Letters 16, 6710-6721.

Anonymous, 2014. Directorate of Economics and Statistics. Department of Agriculture and Cooperation. Ministry of Agriculture, Government of India.

Arnon, D.I., 1949. Copper enzymes in isolated chloroplast: Polyphenoloxidase in Beta Vulgaris. Plant Physiology 24, 1-15.

Baninasab, B., Ghobadi, C., 2011. Influence of paclobutrazol and application methods on high-tempeature stress injury in cucumber seedlings. Journal of Plant Growth Regulation 30, 213-219.

Berova, M., Zlatev, Z., 2003. Physiological response of paclobutrazol treated triticale plants to water stress. Biologia Plantarum 46, 133-136.

Bisht, R., Singariya, P., Bohra, S.P., Mathur, N., 2007. Triazoles: Their effects on net photosynthetic rate, transpiration rate and stomatal resistance in Setaria italica plants grown in vivo. Asian Journal of Experimental Science 21, 271-276.

Burden, R.S., James, C.S., Cooke, D.T., Anderson, N.H., 1987. C-14 demethylation in phytosterol biosynthesis- a new target site for herbicidal activity. In: Proceedings of Brighton Crop Protection Conference on Weeds 3, 171-178.

Chaney, W.R., 2003. Tree Growth Retardants: Arborists discovering new uses for an old tool. Tree Care Industry Magazine 54, 2-6.

Faulkner, S.P., Patrick, W.H., Gambrell, R.P., 1989. Field techniques for measuring wetland soil parameters. Soil Science Society of America Jouranal 53, 883-890.

Fletcher, R.A., Hofstra, G., 1990. Improvement of uniconazoleinduced protection in wheat seedlings. Journal of Plant Growth Regulation 9, 207-212.

Fletcher, R.A., Gilley, A., Davis, T.D., Sankhla, N., 2000. Triazoles as plant growth regulators and stress protectants. Horticultural Reviews 24, 55-138.

Gopi, R., Jaleel, C., Sairam, R., Lakshmanan, G.M.A., Gomathinayagam, M., Panneerselvam, R., 2007. Differential effects of hexaconazole and paclobutrazol on biomass, electrolyte leakage, lipid peroxidation and antioxidant potential of Daucus carota L. Colloid Surface B: Biointerfaces 60, 180-186.

Hiscox, J.D., Isralstam, G.F., 1979. A method for extraction of chlorophyll from leaf tissue without maceration. 
Canadian Journal of Botany 57, 1332-1334.

Iturbe-Ormaetxe, I., Escuredo, P.R., Arrese-Igor, C., Becana, M., 1998. Oxidative damage in pea plants exposed to water deficit or paraquat. Plant Physiology 116, 173-181.

Jaleel, C.A., Gopi, R., Manivannan, P., Panneerselvam, R., 2007. Responses of antioxidant defense system of Catharanthus roseus (L.) G. Don. to paclobutrazol treatment under salinity. Acta Physiologia Plantarum 29, 205-209.

Jungklang, J., Saengnil, K., 2012. Effect of paclobutrazol on patumma cv. Chiang Mai Pink under water stress. Songklanakarin Jounal of Science and Technology 34, 361-366.

Kishor, A., Srivastav, M., Dubey, A.K., Singh, A.K., Sairam, R.K., Pandey, R.N., Dahuja, A., Sharma, R.R., 2009. Paclobutrazol minimizes salt stress effects in mango (Mangifera Indica L.). Journal of Horticultural Science and Biotechnology 84, 459-465.

Lin, K.H., Pai, F.H., Hwang, S.Y., Lo, H.F., 2006. Pre-treating with paclobutrazol enhanced chilling tolerance of sweet potato. Plant Growth Regulation 49, 249-262.

Massacci, A., Nabiev, S.M., Pietrosanti, L., Nematov, S.K., Chernikova, T.N., Thor, K., Leipner, J., 2008. Response of the photosynthetic apparatus of cotton (Gossypium hirsutum) to the onset of drought stress under field conditions studied by gas-exchange analysis and chlorophyll fluorescence imaging. Plant Physiology and Biochemistry 46, 189-195.

Nouriyani, H., Majidi, E., Seyyednejad, S.M., Siadat, S.A., Naderi, A., 2012. Effect of paclobutrazol under different levels of nitrogen on some physiological traits of two wheat cultivars (Triticum aestivum L.). World Applied Science Journal 16, 1-6.

Percival, C., Noviss, K., 2008. Triazole induced drought tolerance in horse chestnut (Aesculus hippocastanum). Tree Physiology 28, 1685-16.

Premachandra, G.S., Saneoka, H., Ogata., 1990. Cell membrane stability an indicator of drought tolerance as affected by applied $\mathrm{N}$ in soybean. Journal of Agriculture Sciences 115, 63-66.

Rady, M., Gaballah, S., 2012. Improving Barley Yield Grown Under Water Stress Conditions. Res. Research Journal of Recent Science 1(6), 1-6.

Rahman, H., Khan, M., Khokhar, M., 1989. Effect of paclobutrazol on growth and yield of tomato. Pakistan Journal of Agiculural Research 10, 49-51.

Rao, D.L.N., Giller, K.N., Yeo, E.R., Flowers, T.J., 2002. The effect of salinity and sodicity upon nodulation and nitrogen fixation in chickpea (Cicer arietinum L.). Annals of Botany 89(5), 563-570.

Sankar, B., Jaleel, C.A., Manivannan, P., Kishorekumar, A., Somasundaram, R., Panneeelvam, R., 2007. Effect of paclobutrazol on water stress amelioration through antioxidants and free radical scavenging enzymes in Arachis hypogaea L. Colloid Surface B:Biointerfaces 60, 229-235.

Smirnoff, N., 1995. Antioxidant systems and plant responses to the environment. In: Smirnoff, V. (Ed.), Environment and Plant Metabolism: Flexibility and Acclimation, Bios Scientific Publishers, Oxford, UK, 217-243.

Toker, C., Cagirgan, M., 1998. Assessment of response to drought stress of chickpea (Cicer arietinum L.) lines under rain field conditions. Turkish Journal of Agro Forestry 22, 615-621.

Weatherly, P.E., 1950. Studies of the water relations of the cotton plant II. Diurnal and seasonal variations in relative turgidity and environmental factors. New Phytology 50, 36-51.

Yan, X.H., Pan, R.Z., 1992. Effects of triadimefon on the growth, photosynthesis and respiration of groundnut seedlings. Oil Seed Crops (China) 4, 57.

Zhu, L., Welander, M., Peppel, A., Li, X., 2004. Changes of leaf water potential and endogenous cytokinins in young apple trees treated with or without paclobutrazol under drought conditions. Scientia Horticulturae 99, 133-141. 